\title{
Prognostic impact of p16 and p53 gene expressions in stage 1a epithelial ovarian cancer
}

Emre Günakan, MD', Yusuf Aytaç Tohma, MD', Latife Atasoy Karakaş, MD', Hüseyin Akıllı, MD², Asuman Nihan Haberal, MD², Ali Ayhan, MD'

Departments of ${ }^{1}$ Obstetrics and Gynecology, ${ }^{2}$ Pathology, School of Medicine, Başkent University, Ankara, Turkey

\section{Objective}

Epithelial ovarian cancer (EOC) is rarely detected at stage 1a. Most of the patients have a good prognosis and there are limited factors that affect their survival. In the present study, we evaluated the p16 and p53 gene expressions of stage 1a EOC patients. Prognostic effects of these gene expressions, as well as those of other factors on short term survival were analyzed.

\section{Methods}

Our study included 29 patients. The specimens of the ovary with cancer were stained for p16 and p53. Gene expressions and other prognostic factors were evaluated.

Results

The median age of the patients was 51 years (27-84). The mean numbers of dissected pelvic and paraaortic lymph

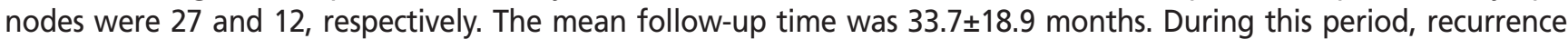
occurred in two patients. One of the patients had grade 2 mucinous carcinoma and died of the disease at month 12 after the recurrence occurred at month 7. The second patient had clear cell carcinoma and recurrence occurred at month 34. p16 and p53 gene expressions or other factors were not associated with overall survival (OS) or diseasefree survival in the short term. The lower p16 positivity rate in the non-clear cell group was found to be statistically significant $(P=0.003)$. Both $\mathrm{p} 53$ and $\mathrm{p} 16$ positivity rates were higher in the high-grade carcinoma.

\section{Conclusion}

The levels of none of the common prognostic factors, including those of $p 16$ and p53 gene expression, were associated with the progression-free survival or OS of stage 1a in the short term. Appropriate surgical staging and non-omission of subclinical metastases seem to be of central importance.

Keywords: Disease-free survival; Genes, p16; Genes, p53; Progression-free survival

\section{Introduction}

Ovarian cancer is usually diagnosed at advanced stages. It is the most lethal gynecological cancer and accounts for $4.3 \%$ of all cancer-related deaths [1]. Advanced-stage epithelial ovarian cancer $(E O C)$ is the leading subject of research in literature compared to early-stage disease. However, most early-stage disease-related studies evaluate the patients with stage 1 or 2 together, even though stage $1 \mathrm{a} / 1 \mathrm{~b}$ disease has a better prognosis than stage $1 \mathrm{c}$ or 2 [2].

Stage 1a EOC constitutes a minor group (up to 10\%) of patients, with a 5 -year survival rate of over $90 \%$ [3]. There are several prognostic factors associated with stage $1 \mathrm{a}$
Received: 2019.10.26. Revised: 2020.02.10. Accepted: 2020.02.17. Corresponding author: Emre Günakan, MD

Department of Obstetrics and Gynecology, School of Medicine, Başkent University, Fevzi Çakmak Cd. 10. Sk. No:45 Bahçelievler, Ankara, Turkey

E-mail: emreg43@hotmail.com

https://orcid.org/0000-0001-8854-8190

Articles published in Obstet Gynecol Sci are open-access, distributed under the terms of the Creative Commons Attribution Non-Commercial License (http://creativecommons. org/licenses/by-nc/3.0/) which permits unrestricted non-commercial use, distribution, and reproduction in any medium, provided the original work is properly cited.

Copyright $\odot 2020$ Korean Society of Obstetrics and Gynecology 


\section{Obstetrics \& Gynecology Science}

Emre Günakan, et al. p16, p53 genes in stage1a ovarian cancer

disease, including age, histological factors (e.g., type and grade), and molecular factors such as abnormal oncogene expression (e.g., p53, p16, Her2/neu, PTEN, p21, and ki67).

p16 is a cyclin-dependent kinase (CDK) inhibitor that inhibits retinoblastoma protein levels by inhibiting CDK phosphorylation during cell cycle progression. Another mode of its action involves the inhibition of cyclin D1, which inactivates pRb through CDK4. Both p16 and pRb are important tumor suppressors in cell cycle regulation. p16 is a potent inhibitor of CDK4 and CDK6. p16, pRb, and cyclin are involved in the transition from the $\mathrm{G} 1$ to $S$ phase, which is the most important control point of the D1 cell cycle. The p53 protein is localized in the nucleus and plays a role in the mechanisms underlying DNA damage repair. p53 controls the transition from the G1 to $S$ phase. It is the most common site of genetic change in human tumors [4]. Approximately, $50 \%$ of human tumors contain a p53 gene mutation. Additionally, several studies have reported about the high p53 mutation rate in EOC [5-7]. Recently, mutation or promoter methylation of the p16 gene has also been detected in ovarian serous adenocarcinoma [8]. In the current study, we aimed to evaluate the effect of p16 and p53 expressions and conventional prognostic factors on stage $1 \mathrm{a}$ EOC. gery for EOC at the Department of Gynecologic Oncology, School of Medicine, Başkent University and were diagnosed with stage 1a disease. The study was conducted in accordance with the Declaration of Helsinki. Standard staging surgery included hysterectomy, bilateral salphingo-oophorectomy, bilateral pelvic and paraaortic lymph node dissection, omentectomy, and appendectomy. Uterus and one ovary were preserved and unilateral salphingo-oophorectomy was performed in fertility-sparing surgery. The International Federation of Gynecologists and Obstetricians (FIGO) system was used for disease staging [9]. Patients were evaluated in groups based on the histological type (clear and non-clear cell carcinoma) and the presence or absence of p16 and p53 gene expressions. p16 and p53 expressions were evaluated immunohistochemically in paraffin blocs. Nuclear staining in the epithelial cells was evaluated under a light microscope. Lack of staining, slight staining, or staining of less than $10 \%$ of the tumor cells was defined as negative, while others were defined as positive (Fig. 1). Data were analyzed using SPSS for Windows v.15.0 (SPSS Inc., Chicago, IL, USA). Descriptive and frequency analyses were performed. Categorical variables were compared using the chi-square test or Fisher's exact test, as appropriate. The level of statistical significance was set at $P<0.05$.

\section{Materials and methods}

Our study included 29 patients who underwent staging sur-

\section{Results}

Our study included 29 patients. The median age of the pa-
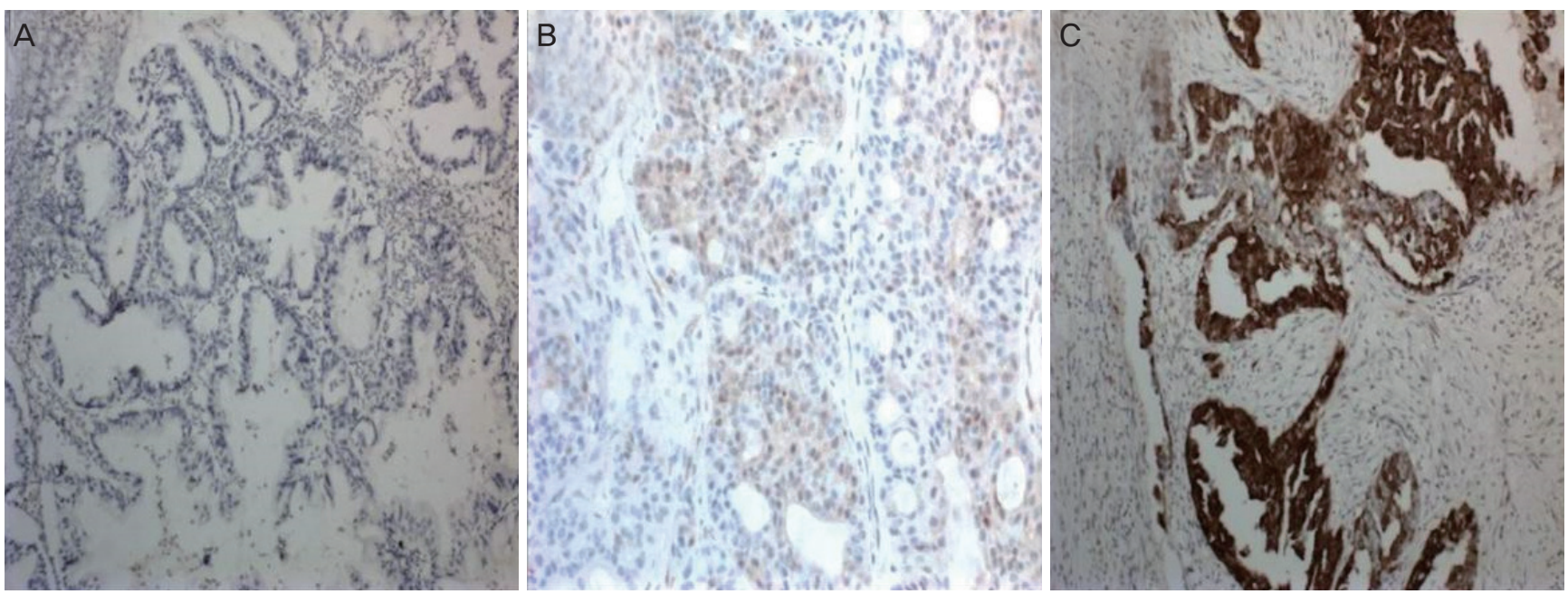

Fig. 1. (A) Weak staining pattern with p16 marker ( $\times 10$ high-power field [HPF]); (B) Moderate staining pattern with p16 marker ( $\times 20 \mathrm{HPF})$; (C) Strong staining pattern with p16 marker (×10 HPF). 


\section{Obstetrics \& Gynecology Science}

Vol. 63, No. 4, 2020

tients was 51 (27-84). The number of premenopausal and postmenopausal patients were $14(48.2 \%)$ and 15 (51.8\%), respectively. The general properties of the patients are summarized in Table 1. The mean numbers of dissected pelvic and paraaortic lymph nodes were 27 and 12, respectively. The mean tumor diameter was $11.5 \pm 1.1 \mathrm{~cm}$.

Table 2 summarizes the staining patterns for p53 and p16 according to the histological types. p53 was positive in all

Table 1. General properties of patients

\begin{tabular}{lc}
\hline Variables & Values \\
\hline Age & $22(75)$ \\
$\leq 60$ & $7(25)$ \\
$>60$ & \\
Histological type & $12(41)$ \\
Clear cell & $17(59)$ \\
Non-clear cell & \\
Menopausal status & $14(48)$ \\
Premenopausal & $15(52)$ \\
Postmenopausal & \\
Surgical approach & $26(89)$ \\
Standard & $3(11)$ \\
Fertility sparing & \\
Follow-up (mon) & 12 \\
Min & 70 \\
Max &
\end{tabular}

Values are presented as number (\%). specimens of patients with clear cell histology. The lower p16 positivity rate in the non-clear cell group was found to be statistically significant $(P=0.003)$. Furthermore, both p53 and p16 positivity rates were higher in the high-grade tumor, and this was statistically significant for the $p 16$ group $(P=0.048)$.

The mean follow-up time was $33.7 \pm 18.9$ months. During this period, recurrence occurred in two patients and one of these patients died of the disease. One of the patients had grade 2 mucinous carcinoma and died of disease at month 12 after a recurrence at month 7 . The second patient had clear cell carcinoma and recurrence occurred at month 34 . She was subjected to a combined chemotherapeutic regimen that included the administration of paclitaxel and carboplatin after a secondary cytoreduction. She was alive at t month 42 of the follow-up. The levels of none of the prognostic factors, including those of $p 16$ and $p 53$ gene expression, were statistically significant in the disease-free survival (DFS) or overall survival analyses in the short term (Table 3).

\section{Discussion}

Stage 1a EOC is defined as the disease that is confined to one of the ovaries with intact surface epithelium and no other metastases. Thus, only a few prognostic factors are associated with the tumor. Histological type and grade are the globally well-accepted factors, and in addition, molecular patterns have been found to be related to tumor behavior.

Table 2. The staining patterns for p53 and p16 according to the histopathological evaluation

\begin{tabular}{|c|c|c|c|c|c|c|}
\hline Variables & p53+ & p53- & $P$-value & p16+ & p16- & $P$-value \\
\hline \multicolumn{7}{|l|}{ Histological type } \\
\hline Clear cell & $9(75.0)$ & $3(25.0)$ & 0.498 & $12(100)$ & $0(0)$ & 0.130 \\
\hline Non-clear cell & $9(56.3)$ & $7(43.8)$ & & $15(88.2)$ & $2(11.8)$ & \\
\hline \multicolumn{7}{|c|}{ Non-clear subtypes } \\
\hline Endometrioid & $3(75)$ & $1(25)$ & 0.279 & $4(100)$ & $0(0)$ & 0.003 \\
\hline Mucinous & $0(0)$ & $8(100)$ & & $6(75.0)$ & $2(25.0)$ & \\
\hline Serous & $4(80)$ & $1(20)$ & & $5(100)$ & $0(0)$ & \\
\hline \multicolumn{7}{|l|}{ Grade $^{a)}$} \\
\hline 1 & $6(75)$ & $2(25)$ & 0.06 & $3(37.5)$ & $5(62.5)$ & 0.048 \\
\hline 2 & $5(100)$ & $0(0)$ & & $1(20.0)$ & $4(80.0)$ & \\
\hline 3 & $16(100)$ & $0(0)$ & & $12(75.0)$ & $4(25.0)$ & \\
\hline
\end{tabular}

Values are presented as number (\%).

${ }^{\text {a) }}$ Clear cell tumors were involved in grade 3 group due to the agressive nature. 


\section{Obstetrics \& Gynecology Science}

Emre Günakan, et al. p16, p53 genes in stage1a ovarian cancer

Table 3. Survival analysis of prognostic factors

\begin{tabular}{|c|c|c|c|c|}
\hline Variables & DFS & $P$-value & OS & $P$-value \\
\hline Age & & 0.224 & & 0.226 \\
\hline$<60$ & $22(35.8 \pm 20.7)$ & & $22(36.0 \pm 20.4)$ & \\
\hline$>60$ & $7(25.6 \pm 10.0)$ & & $7(26.7 \pm 11.5)$ & \\
\hline Histological type & & 0.182 & & 0.161 \\
\hline Clear cell & $12(39 \pm 18.2)$ & & $12(39.67 \pm 18.2)$ & \\
\hline Non-clear cell & $17(29.3 \pm 19.1)$ & & $17(29.6 \pm 18.8)$ & \\
\hline Grade & & 0.536 & & 0.489 \\
\hline 1 & $8(26.9 \pm 14.0)$ & & $8(26.9 \pm 14.0)$ & \\
\hline 2 & $5(34.0 \pm 22.3)$ & & $8(35.0 \pm 20.9)$ & \\
\hline 3 & $16(36.3 \pm 20.5)$ & & $16(36.8 \pm 20.6)$ & \\
\hline p16 & & 0.078 & & 0.103 \\
\hline Positive & $16(38.9 \pm 19.9)$ & & $16(38.94 \pm 19.9)$ & \\
\hline Negative & $13(26.3 \pm 16.0)$ & & $13(27.38 \pm 16.1)$ & \\
\hline p53 & & 0.297 & & 0.277 \\
\hline Positive & $27(34.3 \pm 19.3)$ & & $27(34.8 \pm 19.1)$ & \\
\hline Negative & $2(19.5 \pm 9.1)$ & & $2(19.1 \pm 9.1)$ & \\
\hline
\end{tabular}

Values are presented as number (mean \pm standard deviation).

DFS, disease-free survival; OS, overall survival.

The aim of our study was to investigate whether p53 and p16 expressions affect survival in stage 1a EOC. In the current analysis, we did not find a statistically significant association between survival and the levels of any of the factors, including those of $p 53$ and $p 16$ expression, in the short term.

The initial approach in early-stage ovarian cancer treatment is surgical staging. These results constitute the basis of adjuvant treatment and prediction of prognosis $[10,11]$. Additionally, there is no difference in 5-year survival expectancy between fertility-sparing or radical surgery at stage $1[12,13]$. In stage 1a disease, classic staging procedure is sufficient and curative in a substantial proportion of patients. Observational studies have shown that $30 \%$ of patients, who were thought to have stage I or II disease during the initial surgery, were diagnosed with a more advanced stage disease after more comprehensive restaging laparotomy [14]. In a study comprising 138 patients, the recurrence rates of complete and incomplete staging were $10 \%$ and $28 \%$, respectively [15]. At this point, the main targets of the surgery in patients who are thought to have early-stage disease should be appropriate staging procedure and the exclusion of occult and subclinical metastases [16]. In our study, all patients were subjected to a standard staging surgery with an adequate number of lymph nodes in both the pelvic and paraaortic regions.

Endometrioid histology is associated with a better prognosis and an earlier stage at the time of diagnosis [17]. Contrastingly, clear cell histology is associated with poor prognosis [3]. In addition, clear cell histology has an aggressive nature and can be considered as a high-grade tumor. Even stage 1a patients with clear cell carcinoma undergo adjuvant therapies. Clear cell histology was the most frequent histological type in our study and was evaluated as a separate group. All specimens were p53-positive and this was a conspicuous point.

In the cell cycle, DNA damage is controlled at the G1/S control point and DNA repair mechanisms are activated. Mutation of the p53 tumor suppressor gene results in a DNA repair failure leading to neoplastic development [18]. Mutation of p53 is frequently detected in high grade serous ovarian cancers, and this frequency may be up to $80 \%$ in advanced stages [19]. Over-expression of p53 is associated with poor prognosis [20-25] and high tumor grade [24]. Additionally, p53 was associated with lower DFS and poor prognosis in stages 1 and $2[21,22]$. Association of p16 and EOC is a relatively less evaluated issue compared to p53. In contrast, p16 


\section{Obstetrics \& Gynecology Science}

Vol. 63, No. 4, 2020

gene mutations or promoter methylation has been detected in serous ovarian cancer in recent years [8]. Moreover, p16 over-expression is associated with high differentiation and tumor grade [26], advanced-stage [8], and poor prognosis [27]. Similar previously published studies have commonly focused on advanced stage disease or stage 1 and 2 disease together. In the current study, we investigated the effect of these molecular changes in stage 1a differently from other studies. We found some significant histopathological findings, whereas its effect on survival could not be well-established due to the short follow-up time.

Stage 1a EOC patients were included in the current study to minimize heterogeneity. Prognostic factors, including p53 and p16 expressions, were evaluated and initial reports of short-term results are reported herein. Standard surgical and medical management of a single-center and uniform patient selection should be considered the strengths of this study. However, the short follow-up time and a limited number of patients should be considered the limitations. The long-term results will be also presented in the future.

\section{Conflict of interest}

No potential conflict of interest relevant to this article was reported.

\section{Ethical approval}

The study was approved by the review board of the University of Medical Sciences.

\section{References}

1. Ferlay J, Soerjomataram I, Dikshit R, Eser S, Mathers C, Rebelo $\mathrm{M}$, et al. Cancer incidence and mortality worldwide: sources, methods and major patterns in GLOBOCAN 2012. Int J Cancer 2015;136:E359-86.

2. Chan JK, Tian C, Monk BJ, Herzog T, Kapp TS, Bell J, et al. Prognostic factors for high-risk early-stage epithelial ovarian cancer. Cancer 2008;112:2202-10.

3. Ayhan A, Reed N, Gultekin M, Dursun P. Early stage epithelial ovarian cancer. In: Ayhan A, Reed N, Gultekin M,
Dursun P, editors. Textbook of gynaecolgical oncology. 2nd ed. Ankara: Güneş Tıp Kitapevleri; 2011. p.429-31.

4. Vousden KH, Lane DP. p53 in health and disease. Nat Rev Mol Cell Biol 2007;8:275-83.

5. Ayhan A, Reed N, Gultekin M, Dursun P. prognostic factors for gynecologic cancers. In: Ayhan A, Reed N, Gultekin M, Dursun P, editors. Textbook of gynaecolgical oncology. 2nd ed, Ankara: Güneş Tıp Kitapevleri; 2011. p.1056-60.

6. McMenamin ME, O'Neill AJ, Gaffney EF. Extent of apoptosis in ovarian serous carcinoma: relation to mitotic and proliferative indices, p53 expression, and survival. Mol Pathol 1997;50:242-6.

7. Singer G, Kurman RJ, Chang HW, Cho SK, Shih IM. Diverse tumorigenic pathways in ovarian serous carcinoma. Am J Pathol 2002;160:1223-8.

8. Katsaros D, Cho W, Singal R, Fracchioli S, Rigault De La Longrais IA, Arisio $R$, et al. Methylation of tumor suppressor gene p16 and prognosis of epithelial ovarian cancer. Gynecol Oncol 2004;94:685-92.

9. Rodriguez M, Nguyen HN, Averette HE, Steren AJ, Penalver MA, Harrison T, et al. National survey of ovarian carcinoma XII. Epithelial ovarian malignancies in women less than or equal to 25 years of age. Cancer 1994;73:1245-50.

10. Schildkraut JM, Halabi S, Bastos E, Marchbanks PA, McDonald JA, Berchuck A. Prognostic factors in early-onset epithelial ovarian cancer: a population-based study. Obstet Gynecol 2000;95:119-27.

11. Zanetta G, Rota S, Chiari S, Bonazzi C, Bratina G, Torri V, et al. The accuracy of staging: an important prognostic determinator in stage I ovarian carcinoma. A multivariate analysis. Ann Oncol 1998;9:1097-101.

12. Ayhan A, Celik H, Taskiran C, Bozdag G, Aksu T. Oncologic and reproductive outcome after fertilitysaving surgery in ovarian cancer. Eur J Gynaecol Oncol 2003;24:223-32.

13. Colombo N, Chiari S, Maggioni A, Bocciolone L, Torri V, Mangioni $C$. Controversial issues in the management of early epithelial ovarian cancer: conservative surgery and role of adjuvant therapy. Gynecol Oncol 1994;55:S4751.

14. Mutch DG. Ovarian and tubal cancers. In: Gibbs RS, Karlan BY, Haney AF, Nygaard IE, editors. Danforth's obstetrics and gynecology. 10th ed. Philadelphia (PA): Lip- 


\section{Obstetrics \& Gynecology Science}

Emre Günakan, et al. p16, p53 genes in stage1a ovarian cancer

pincott Williams \& Wilkins; 2008. p.1023-60.

15. Le T, Adolph A, Krepart GV, Lotocki R, Heywood MS. The benefits of comprehensive surgical staging in the management of early-stage epithelial ovarian carcinoma. Gynecol Oncol 2002;85:351-5.

16. Chan J, Fuh K, Shin J, Cheung M, Powell C, Chen LM, et al. The treatment and outcomes of early-stage epithelial ovarian cancer: have we made any progress? Br J Cancer 2008;98:1191-6.

17. Seidman JD, Kurman RJ. Pathology of ovarian carcinoma. Hematol Oncol Clin North Am 2003;17:909-25.

18. Ellenson LH, Pirog EC. The female genital tract. In: Kumar V, Abbas AK, Fausto N, editors. Robbins and Cotran pathologic basis of disease. 7th ed. Philadelphia (PA): Elsevier Saunders; 2005. p.1092-104.

19. Kurman RJ, Shih IM. Pathogenesis of ovarian cancer: lessons from morphology and molecular biology and their clinical implications. Int J Gynecol Pathol 2008;27:15160.

20. Darcy KM, Brady WE, McBroom JW, Bell JG, Young RC, McGuire WP, et al. Associations between p53 overexpression and multiple measures of clinical outcome in high-risk, early stage or suboptimally-resected, advanced stage epithelial ovarian cancers A Gynecologic Oncology Group study. Gynecol Oncol 2008;111:487-95.

21. Skírnisdóttir IA, Sorbe B, Lindborg K, Seidal T. Prognostic impact of p53, p27, and C-MYC on clinicopathological features and outcome in early-stage (FIGO I-II) epithelial ovarian cancer. Int J Gynecol Cancer 2011;21:236-44.

22. Skírnisdóttir I, Seidal T. Prognostic impact of concomitant p53 and PTEN on outcome in early stage (FIGO I-II) epithelial ovarian cancer. Int J Gynecol Cancer 2011;21:1024-31.

23. de Graeff $P$, Crijns AP, de Jong $S$, Boezen M, Post WJ, de Vries EG, et al. Modest effect of p53, EGFR and HER-2/ neu on prognosis in epithelial ovarian cancer: a metaanalysis. Br J Cancer 2009;101:149-59.

24. García-Velasco A, Mendiola C, Sánchez-Muñoz A, Ballestín $\mathrm{C}$, Colomer R, Cortés-Funes H. Prognostic value of hormonal receptors, p53, ki67 and HER2/neu expression in epithelial ovarian carcinoma. Clin Transl Oncol 2008;10:367-71.

25. Lee YK, Park NH. Prognostic value and clinicopathological significance of p53 and PTEN in epithelial ovarian cancers. Gynecol Oncol 2009;112:475-80.

26. Khouja MH, Baekelandt M, Nesland JM, Holm R. The clinical importance of Ki-67, p16, p14, and p57 expression in patients with advanced ovarian carcinoma. Int J Gynecol Pathol 2007;26:418-25.

27. Surowiak P, Materna V, Maciejczyk A, Pudelko M, Suchocki S, Kedzia W, et al. Decreased expression of p16 in ovarian cancers represents an unfavourable prognostic factor. Histol Histopathol 2008;23:531-8. 